\title{
Teaching and Learning SoTL: Preparing Future Faculty in a Pedagogy Course
}

\begin{abstract}
The Scholarship of Teaching and Learning (SoTL) offers a way of equipping graduate students for monitoring, assessing, and reflecting on their teaching and their students' learning in higher education. After reviewing recent literature about the ways graduate students prepare for teaching, this essay presents an example of one way SoTL can inform teaching and teacher education as part of a graduate seminar. When a SoTL approach was integrated into a course about teaching in higher education, the course itself became a faculty-graduate student collaborative project. This essay demonstrates the potent circularity of the reflective teaching practice that drives the course and inspires similar practice in its students, which in turn informs subsequent iterations of the course.
\end{abstract}

\section{KEYWORDS}

graduate students, SoTL, TA training, teacher education, pedagogy education, faculty development

\section{INTRODUCTION}

Teacher training for the professoriate once seemed unnecessary. After all, higher education has traditionally prioritized scholarship, and the work of sharing knowledge often has been assumed to emerge simply from faculty enthusiasm for their subjects. But in the face of economic, political, and social pressures for accountability about student learning and faculty teaching, academic institutions have been challenged to pay more attention to preparing future faculty as teachers as well as scholars. Recent higher education research argues for the Scholarship of Teaching and Learning (SoTL) as a way to improve teaching in the academy. This essay will show how SoTL concepts, tools, and strategies are well suited for (re)constructing the curriculum to bring more effective teacher education into programs of graduate study, helping students "move from thinking of teaching as performance to viewing their teaching as an intellectual process" (Hodges, 2013, p. 77) with an "emphasis on methods, reflection, and dialogue rather than on outputs" (Fanghanel, 2013, p. 62). After reviewing recent literature about preparing graduate students for teaching in higher education, we map the progress of one such course from two perspectives: that of the course instructor and that of a former student in the course who is now teaching. Our aim is to demonstrate a SoTL approach to a teacher education 
course: valuing students as learners and emphasizing their stake in their own education, positioning teachers in training as active investigators of the learning process and observers of teaching strategies, encouraging new teachers to create similar inquiry-based assignments with their own students, and not fearing student feedback but welcoming it as a potentially valuable resource. The essay reflects on the way SoTL can alter students' thinking about teaching and scholarship as symbiotic, rather than competing, practices so they go on to enrich their own teaching and foster collaborative work with students and faculty colleagues alike.

\section{HOW SOTL CAN ENHANCE GRADUATE TEACHER EDUCATION}

A common approach to teacher education in North American universities has been Teaching Assistant (TA) training for students who receive funding from their graduate program in exchange for classroom teaching duties. Such "practicum" courses traditionally have focused on the immediate needs of TAs for classroom support and practical advice about creating syllabi and assignments, grading papers, and handling class discussion during the first months of university teaching (Chism, 1998; Latterell, 1996; Pytlik \& Liggett, 2002). Training programs for graduate teaching assistants (GTAs) in the United Kingdom, too, traditionally have been peremptory, since "the more common model in the UK is still the graduate student who teaches, [but] whose main role is as a research student" (Park, 2004, p. 349). But the sense of teacher education as a distraction rather than a central concern in preparing students for academic work seems irresponsible in the face of a cloudy employment outlook that places new importance on teaching (Boman, 2008; Chism, 1998; Park, 2004;Wulff \& Austin, 2004).

Education experts agree that "a significant shift has taken place since the early 1990s in terms of how teaching is being conceptualized" at the university level (Fanghanel, 2013, p. 61). Therefore, as Hutchings and Clarke put it, "One might argue that the scholarship of teaching and learning is especially important in graduate education ... [and] should be at the very heart of graduate education reform efforts" $(2004,166)$. This is not a simple prescription. Graduate students already may feel overtaxed by the competing demands of course work, research, and teaching duties. Moreover, when "the emphasis on teaching and learning appears to distract graduate students from their own research careers and their support of faculty research projects, it threatens the cultural expectations and habits cherished by many faculty and administrators" (Hutchings \& Clarke, 2004, p. 164). However, SoTL has been described as "a paradigmshifting method of inquiry-emphasizing the local, collaborative, and dialogic nature of practice and the transformation of practice through inquiry" (Fanghanel, 2013, p. 62). It is this very paradigm shift that, far from undermining treasured academic practices, may enhance our scholarly culture of collaboration and investigation not only within graduate and undergraduate classrooms but also in graduate teacher education.

As collaborative scholars of teaching, we wanted to reflect on the roots of our partnership in a graduate pedagogy seminar in order to examine both how SoTL can enhance teacher education and how teacher education can foster SoTL within the course and beyond. Beginning with a teacher-student relationship in 2009, the co-authors' work together developed into just such a collaboration. They met in LIT 730, a graduate seminar for master's degree students in a university literature department. As taught by Janet Auten (hereafter referred to as Janet), the course is intended to prepare students for teaching 
English composition in higher education. Janet has taught the course since 2000 as an introduction to theories in writing studies (in America, composition studies) and a foundation in practical pedagogy - the ideas, theories, and methodologies that form a foundation for what goes on in a classroom. Margaret Twigg (hereafter, Margaret) took the course in 2009 as part of her MA course work. Like many of the students in the course, she brought solid knowledge of literary and cultural theory to the class but had little teaching experience and no experience of scholarship about teaching. After graduating, she went on to teach first-year English composition, using the collaborative SoTL practice learned in LIT 730 to inform her course development.

\section{A COURSE ABOUT TEACHING AND LEARNING}

Our literature department, in a private, four-year, research-oriented university in Washington, $\mathrm{DC}$ has no $\mathrm{PhD}$ program and attracts master's degree candidates who may elect to take LIT 730, Teaching Composition, to prepare for a classroom internship or inform a teaching assistantship. Like Margaret, students may enter this course under the impression that the literary and cultural theory they are reading and writing about in their other courses is separate from teaching practice. Therefore, they sometimes are perplexed by the course goals, as stated in the syllabus, of exploring "the theoretical, social, and cultural contexts of teaching composition" and writing assignments that demand personal reflection, scholarly reading about education, and even theorizing the classroom.

In 2009, when Margaret entered the course, those assignments included two academic essays and a series of weekly reading response papers, prompted with questions from the instructor. These response papers were submitted weekly for instructor feedback, and later submitted collectively for a grade. In the second half of the course, responses were written into an electronic discussion board on the university's online learning platform, Blackboard. After several years of tinkering with reading lists and writing assignments, Janet had realized that the course must function "as practice in a way of encountering the world rather than mastery of skills or facts, as preparation for a lifetime of thinking like a teacher" (Reid, 2004, p. 16, emphasis original). As she became familiar with SoTL, she sought better ways to situate the course reading assignments in a scholarly conversation, inviting students to examine their own education experience and resulting assumptions, to make personal connections with pedagogical theory, and engage in critical thinking about teaching. Reading response questions prompted students to analyse the arguments of the week's readings, asked them to recall moments from their own school experience that connected to this education scholarship, and finally pressed them to discuss how the theoretical and scholarly readings illuminated their student experiences - and vice versa.

Margaret found the response questions helped her to examine, and assess, those readings in pedagogical theory, not as prescriptions but as part of an array of possibilities for enhancing student learning. For example, Pratt's ideas about encouraging multiple viewpoints and cultural perspectives in "Arts of the Contact Zone" coincided with Margaret's own interest in bringing queer theory into her teaching. As she wrote in her response, "The appeal of a classroom that lives by the tenets behind the contact zone (even if it does not always adhere to its specific content and practices) is its ability to provide students with the opportunity to view and practice writing as a way to convey their ideas to each other as well as to the instructor." By allowing her to read the various theories of pedagogy as scholarly research rather than "how to" prescriptions, these response as- 
signments met Margaret where she was comfortable, yet steered her away from simply parroting pedagogical practices wholesale. As a result, she found herself considering not just what she wanted to teach or how she wanted to teach but what kind of teacher those choices might make her. In this way, the assignments pushed students to consider developing teaching identities that were not static "impressions" of one teacher or theorist's practice, but rather performances shaped by scholarly and personal influences, then honed by experimentation and reflection.

The first of the two longer essay assignments in the LIT 730 course zeroes in on those personal influences by privileging student experiences, asking them not to "pretend" to be teachers, but to evaluate teaching environments as students and to analyze their personal learning history. To do so, students narrate one or two particular incidents in their literacy education and discuss their significance in terms of teaching and their learning. This education "autobiography" is a common assignment in English education (Britzman, 2003; Reid, 2009; Stancliff \& Goggin, 2007; Stenberg, 2005; Vinz, 1997) but an important one for a SoTL framework because it values what students already know and helps them "reconceive the teacher as a complex subject who brings a complicated pedagogical history to the classroom that is itself deserving of inquiry" (Stenberg, 2005, p. xxii).

However, many students feel uncomfortable with personal reflection in a school setting. As we discussed this discomfort in class, we found it seemed to stem from the conflicting advice the academy offers to student writers and to teachers about the use of personal narrative in academic writing. Several students pointed out that most academic writing assignments, whether at the graduate or undergraduate level, discourage students from incorporating personal elements into their writing. Subsequent conversations uncovered another layer of complexity embedded in this assignment. It called on students to do something that they had rarely been asked to do outside the context of perfunctory teacher evaluations: to critique past teachers' methods from their position as learners. Janet had found in earlier semesters that many of the resulting "learning autobiographies" gravitated toward impressionable early teen years and a moment of disenchantment or frustration with academic assignments. "Mrs. F.asked us one day . . .to write an essay about nature. She gave us no boundaries other than it might be read by other classmates," one student lamented. "We were given no other inspiration than the white cinder-block walls." Janet's reading and observation confirmed the pitfalls of this literacy narrative assignment: the autobiographical element may point students toward one particular construction of teacher identity based on a memorable mentor, narrow their sense of exploration of teaching approaches, and impede critical analysis in far more complex ways than many graduate instructors might anticipate. Therefore, she had rewritten the assignment for the 2009 class to warn students away from demonizing — or idolizing — the teaching practice of one instructor and toward analyzing what worked (or didn't) about teachers' instructional approaches.

As might be expected, Margaret found it most challenging to evaluate the practices of instructors whom she had previously idealized. But just as her analytic responses to pedagogical theory encouraged her not to become too attached to one theorist, writing this literacy narrative forced her to interrogate even her fondest educational memories analytically. She saw that those moments of connection with students did not come effortlessly to someone who was somehow a "natural" teacher, but rather they were the 
product of years of reflection, revision, and continuous innovation. Just as importantly, she realized that, while certain strategies might have worked for her as a student, they might not have been successful with other students.

If this realization was important for her pedagogical development during her time in LIT 730, it became even more essential once she graduated and began to teach in her own classroom. It is often tempting for new teachers to cherish their victories instead of considering what made them work and how they could be further improved. The interrogation of teaching practice using student experiences, however, forced Margaret to remember that a lesson that goes well may often have more do to with specific students than the instructor. This is a particularly difficult revelation to confront in the early days of teaching when triumphs seem rare. But teachers are much better prepared to confront such uncomfortable realities when they are already accustomed to critiquing the teaching approaches that stand out in their own educational history. Experience with this type of critique also supports reflection on student perspectives, since it begins with the teacher's recall of student experiences. Too often, teachers reflect on their practice in a vacuum, considering alternate strategies without taking into account the wide variety of student responses even minor changes might provoke. As Felten highlights in his five principles of good practice in SoTL, this teacher inquiry focuses on the student's perspective and includes "explorations of how a teaching and teachers influence student learning" (2013, p. 122).

Thus, Margaret found the self-study approach to teaching she learned in LIT 730 encouraged her reflection and revision of lessons, assignments, and activities as a teacher, as much on the days that appeared to be effective as those that were clearly not. She also found herself questioning whether the assignments and lessons that were effective in one class would produce similar results in different groups of students. More importantly, the conversation about student experiences in the teaching seminar helped her see her teaching practice as a dialogue with students instead of a monologue aimed at them. In terms of SoTL practice, as suggested by Felten, she sought to ground her pedagogical choices in the context of that conversation and set out to find ways of exploring students' goals in partnership with students themselves (2013, p. 122-23). For this, she drew on her experience with the literacy narrative, prompting her students to share the diverse literacy experiences that shape their responses to her course goals. She engaged in reflective practice both in conversation with other teachers and in interaction with her students as partners in learning rather than solely subjects of her teaching. Such conversations show how SoTL involves students as co-inquirers (Werder \& Otis, 2010; Felten, 2013).

\section{TEACHER INQUIRY AS MODEL AND MOTIVATION FOR CHANGE}

When it is applied to teacher education, this SoTL approach raises the stakes for making the theoretical underpinnings of the course transparent and offering students an active role in monitoring and assessing their own learning. In nine years of teaching prospective writing instructors, Janet had discovered that, in order to open the pedagogy course to teaching and learning inquiry, one must present the course laid bare-not as a template for "real world" teaching but as a construct, a matter of intentional artifice: let's look at how I built this course; let's examine what we're doing right now, and ask why we're doing it. This puts teacher and students in a partnership of inquiry, another of Felten's 
principles for SoTL practice (2013). The teaching class becomes a laboratory in which teacher and students investigate how a classroom operates, situating not just teachers but also students to study their own learning in context.

But the metacognitive reflexivity that this enterprise demands can represent a high hurdle for students who for various reasons haven't been adequately prepared for the intellectual acrobatics of a meta-analysis of the class itself. To engage students in studying their own present learning means engaging students in "reading" the course-much as they might perform a "close reading" of a literary text - from which themes and ideas emerge about the process of teaching and learning. So besides a foundation of theory and awareness, students need a structure of productive questions that prompt the kind of critical inquiry about teaching and learning that SoTL demands. Janet added assignments that asked specifically for reflective writing as a way of scaffolding students' efforts to make sense of their classroom experience.

A common goal of teacher education at all levels, "reflective practice" has roots in the work of Schön (1990), who championed the importance of reflection-a metacognitive review of experience, action, and/or observation — as both a mode of learning and an avenue to improving one's teaching. But reflection is complex cognitive work. Recent studies have called for more direct, intentional instruction for beginning teachers to convey not only why reflection is important but how to do it (Mena Marcos, Sanchez, \& Tillema, 2011; Ryan, 2013). Janet mined the plentiful literature of reflective practice to create guidelines for short reflection pieces to accompany all written work. These Reflection Paper assignments direct students first to notice their process of responding to the writing assignment, how the assignment "works." Then students are asked to examine the resulting essay in terms of strengths and weaknesses and finally to comment on the effect of the whole writing experience on their thinking and learning.

As they assess the function of the assignment and then address the question of what the writing task taught them, students may come to a clearer, deeper understanding about the role of a writing assignment in the larger context of the course. For example, as one student put it, ${ }^{1}$ the purpose of the literacy narrative becomes clear as "sharing a specific teaching moment meant to illuminate certain theories." Thus "encouraged to notice the assignment prompt and the writing process as pedagogical artifacts, students can use reflection on writing to move into reflection on teaching" (Reid, 2009, p. 212). With their response collections, students submitted a two-page reflection piece as well. With the first collection, they wrote about the experience of navigating between personal experience and scholarship. Some guiding questions encouraged students to move from simply thinking about their own education to probing the larger issues and purposes embedded in writing assignments and syllabi.

Moreover, a SoTL perspective reveals the democratic and dialogic possibilities of this continual engagement in reflective practice: as the teacher reads and responds to students' reflections, the resulting dialogue about student learning ushers in another kind of co-inquiry, another form of the SoTL partnership (Felten, 2013). Teaching becomes " a reciprocal process" (Fanghanel, 2013, p. 61). In 2009, Janet began to make more explicit use of this written dialogue to inform her teaching and at the same time demonstrate teacher inquiry in the second half of the semester by focusing students' attention on the problems and possibilities of teaching with technology. 
In the second half of the 15-week semester, LIT 730 students write their reading responses in the university's electronic classroom platform, Blackboard. Moreover, the burden of prompting and guiding the weekly response writing shifts to students themselves. Each week, three or four students write and post prompts for the class on the discussion board. When students collected and edited their posts to submit for a collective grade, as they did with the responses in the first part of the course, they wrote reflections about the experience of doing the responses online, comparing formats and outcomes with the earlier response papers. Many in the class had experienced online discussion forums in other courses, but the shift from writing reflective reading responses seen only by the instructor to the more public mode of writing - following Shulman's (1993) SoTL trajectory from "pedagogical solitude" to "teaching as community property"-in an online forum caused some consternation. "At first, I was daunted by having to post my responses on Blackboard for the whole class to see," another student wrote. "I was intimidated by having my writing with all of its flaws go public." This time, the reflective writing prompted discussions in class about how the requirement to post online had raised issues of pressure—and privacy. Several students voiced an awareness that, as one put it, "The inability to 'perform' in this public sphere may be crippling for some students, too-and may further alienate them from participating in class discussions or discourage them from believing their voice matters in larger academic or social discussions." Other students raised significant questions about the task of creating writing prompts. They acknowledged problems with knowing how to form an interesting and thought-provoking prompt, fearing they would in turn confuse or mislead other students who respond to that prompt.

In their written reflections, many students, including Margaret, offered thoughtful insights on their learning about the complexity of creating effective writing assignments:

On the surface it appears so much easier to be asking the question instead of answering it, but that is not the case. As a responder to a prompt you only have to think of one answer, while the prompt writer must anticipate multiple ways their question could be interpreted and answered. What's more, the responder thinks primarily of their own ideas, process, and intentions, but the prompt writer must always consider how their writing impacts the processes and purposes of their respondents.

In turn, the in-class discussion joined teacher and students to examine what, why, and how the online discussion board functions. This collaborative and reflective inquiry also bore further fruit in subsequent semesters, as Janet instituted some practical changes: adding some reading and class discussion explicitly concerning crafting good writing assignments and revising the online response assignment to include more explicit attention to and reflection on classmates' posts. The online response assignment continues to evolve as, every semester, she and the students collaboratively consider its effects on class learning. In turn, such discussion models not only a lively learning environment but also a mode of professional collaborative inquiry.

Based on the collaborative inquiry in LIT 730, Margaret brought to her own teaching a grounded, practical view of using technology to bring transparency to her course. While her undergraduates are not teachers in training, they benefit from a collaborative classroom that values their lived experiences, and while some of this collaboration occurs 
in class, online discussion provides a different set of opportunities to achieve this goal. Watching the evolution of Janet's class from a student's perspective raised her awareness of possible pitfalls in her own assignments. For example, most teachers who see online discussion as a "comfortable" place for student responses, a "safer" space than class discussion, would likely be surprised by the paralysis experienced by many of Margaret's classmates.

The most useful part of the Blackboard conversations in LIT 730, from Margaret's perspective, was the practice in writing prompts for discussion. For many students, being given a real opportunity to shape discussion, either in or out of class, was a new experience and obviously an important one for teachers in training. Therefore, once she began teaching, Margaret cultivated opportunities for similar increases in engagement and deeper interaction with course materials by giving students the chance to shape class conversations and deal with the consequences of the directions they chose for those conversations.

Many instructors may be hesitant to hand over more control of their classroom to students at the undergraduate level, but that attitude vastly underestimates the intellectual potential of students. In fact, Margaret had found that students were more likely to be critical of their own ideas when they were aware that both their instructor and their classmates would be responding to them as part of an integrated, collaborative conversation rather than privately. Inspired by her experience in LIT 730, Margaret devised a group assignment for her first-year academic writing class for which students "teach" the class. First, Margaret offers examples of the types of readings productive for class conversation and models questions that help provoke critical analysis of the article. She then asks students to identify at least one source that they plan to use in a researched essay that they also think would also be useful to their classmates. Based on their choices, she creates a "short list" of these articles on Blackboard. Small groups of students each choose one of these articles and prepare a presentation on it. Before presenting, the groups also post collaboratively generated discussion questions on Blackboard to spark conversation both online and in the classroom. In this way, the students not only shape the content of these discussions, they also have a say in writing the questions that their classmates will answer. The resulting conversations make the class a collaborative effort integrating student interests with instructor learning objectives at all levels: course content, reading interpretation, and discussion. What's more, Margaret urges students to draw on their past and present learning experiences to write reflectively about their presentations. The resulting reflection papers have given her evidence that, while undergraduate students do find this level of autonomy intimidating, they also find it brings new awareness to their research, helps them engage with difficult scholarly readings more productively, and makes them more aware of audience in their writing.

\section{CONCLUSION: RETHINKING TEACHER PREPARATION WITH SOTL}

Teaching scholars may view the study of teaching and learning as a natural and selfsustaining activity. However, SoTL skills, like other important habits of mind such as reflection and self-assessment, need to be taught explicitly to prospective faculty. In this paper, we have reflected on the ways - some subtle, some explicit-SoTL can be demonstrated, discussed, and practiced in a teacher education course. SoTL offers an effective approach to prepare teachers in higher education because it offers a way "of studying our teaching, of reading our pedagogical interactions and our pedagogical development ... as texts" (Stenberg \& Lee, 2002, p. 328); because it presents teaching as an object of study 
and positions faculty and students as partners in studying it; and because it integrates critical inquiry and reflection on teaching into the curriculum, positioning students to engage in reflective inquiry about their own learning. This class about classrooms welcomes students "behind the scenes" of teaching, positioning them as teachers analyzing pedagogical choices, seeking evidence of learning (their own and others'), and empowering them to use their experiences as students to inform that analysis. Moreover, the SoTL model of "reading" classrooms - starting with this one-may enhance and supplement more traditional modes of assessment for teachers, whether institutionally mandated course evaluations, simple instructor-generated surveys, or in more formal assessment project designed to generate data about a curriculum.

SoTL-oriented education for teaching offers both theoretical grounding and an understanding of learning that can help graduate students prepare for an academic environment of changes and challenges. It can effectively prepare graduate students to

- analyze and reflect on their teaching - and thus be open to change and growth as teacher

- wrestle with ideas about how new technology affects student learning

- adapt to meet the needs brought by changing student demographics

- adjust to an employment outlook that will probably privilege evidence of education in teaching and demand flexibility.

Such an approach attends to skill-building but also to inquiry, discovery, and reflection.

It is with these goals in mind that our SoTL approach encourages innovation in teacher education. If we can engage students not only in reading SoTL but also in pursuing it themselves, if we can help them read classrooms as well as student papers, and if we can encourage them to share critical inquiry about teaching in their discipline, we allow future teachers to locate themselves as learners and colleagues as well as instructors. By doing so, they define themselves beyond the "teacher narratives we typically celebrate in both scholarly and popular cultural realms [which] tend not to serve as a site for investigation into one's own teacher learning" (Stenberg, 2005, p. 71). Instead, instructor and students at all levels of higher education share in the work of interrogating their identities along with the theories and methods of classroom teaching. If an aim of SoTL is "to uncover the complexity of academic practice through reflection and engagement with relevant partners (colleagues, students)," then the teaching course is surely an ideal laboratory for SoTL practice (Fanghanel, 2013, p. 63). With its focus on student learning, teacher reflection, and teacher-student collaboration, an SoTL approach is remarkably well-suited for graduate student teacher education as well as for the teachers it educates.

Janet $G$. Auten directs the Writing Center and teaches a graduate pedagogy seminar in the Department of Literature at American University in Washington, D.C. (USA)

Margaret M. Twigg is an instructor in the College Writing Program at American University in Washington, D.C. (USA).

\section{NOTES}

1. All quotations from students other than M. Twigg are presented with students' permission and anonymously. 


\section{REFERENCES}

Boman, J. S. (2008). Outcomes of a graduate teaching assistant training program (Doctoral dissertation, University of Western Ontario, Canada). Retrieved from http://search.proquest .com.proxyau.wrlc.org/docview/304319931/abstract?accountid=8285

Britzman, D. P. (2003). Practice makes practice: A critical study of learning to teach (Rev. ed.). Albany: State University of New York Press.

Chism, N. (1998). Preparing graduate students to teach: Past, present, and future. In M. Marincovich, J. Prostko, \& F. Stout (Eds.), The Professional development of graduate teaching assistants (pp. 1-17). Bolton, MA: Anker.

Fanghanel, J. (2013). Going public with pedagogical inquiries: SoTL as a methodology for faculty professional development. Teaching \& Learning Inquiry: The ISSOTL Journal, 1(1), 59-70. doi:10.2979/teachlearninqu.1.1.59

Felten, P. (2013). Principles of good practice in SoTL. Teaching \& Learning Inquiry 1(1). 121125. doi: 10.1353 /iss.2013.0013

Hodges, L. C. (2013). Postcards from the edge of SoTL: A view from faculty development. Teaching \& Learning Inquiry: The ISSOTL Journal, 1(1), 71-79. doi:10.2979/teachlearninqu.1.1.71

Hutchings, P., \& Clarke, S. (2004). The scholarship of teaching and learning: Contributing to reform in graduate education. In D. H. Wulff \& A. E. Austin (Eds.), Paths to the professoriate: strategies for enriching the preparation of future faculty (pp. 161-176). San Francisco: Jossey-Bass.

Latterell, C. G. (1996). Training the workforce: An overview of GTA education curricula. WPA: Writing Program Administration, 19(3), 7-23.

Mena Marcos, J., Sanchez, E., \& Tillema, H.H. (2011). Promoting teacher reflection: What is said to be done. Journal of Education for Teaching, 37(1), 21-36. doi:10.1080/02607476 .2011 .538269

Park, C. (2004). The graduate teaching assistant (GTA): Lessons from North American experience. Teaching in Higher Education, 9(3), 349-361. doi: 10.1080/1356251042000216660

Pratt, M. L. (1991). Arts of the contact zone. Profession, 33-40.

Pytlik, B. P., \& Liggett, S. (Eds.). (2002). Preparing college teachers of writing: Histories, theories, programs, practices. New York: Oxford University Press.

Reid, E. S. (2004). Uncoverage in composition pedagogy. Composition Studies, 32(1), 15-34.

Reid, E. S. (2009). Teaching writing teachers writing: Difficulty, exploration, and critical reflection. College Composition and Communication, 61(2), 197-221.

Ryan, M. (2013). The pedagogical balancing act: Teaching reflection in higher education. Teaching in Higher Education, 18(2), 1-12. doi:10.1080/13562517.2012.694104

Schön, D. A. (1990). Educating the reflective practitioner (1st ed.). San Francisco: Jossey-Bass.

Shulman, L. S. (1993). Teaching as community property: putting an end to pedagogical solitude. Change 25(6): 6-7.

Stancliff, M.I, \& Goggin, M. D. (2007). What's theorizing got to do with it? Teaching theory as resourceful conflict and reflection in TA preparation. Writing Program Administration, $30(3), 11-28$. 
Stenberg, S., \& Lee, A. (2002). Developing pedagogies: Learning the teaching of English. College English, 64(3), 326-47.

Stenberg, S. J. (2005). Professing and pedagogy: Learning the teaching of English. Urbana, III: NCTE.

Vinz, R. (1997). Capturing a moving form: “Becoming" as teachers. English Education, 29(2), 137-146.

Werner, C., \& Otis, M. (2010). Engaging Student Voices in the Study of Teaching and Learning. Sterling, VA: Stylus.

Wulff, D. H., \& Austin, A. E. (Eds.). (2004). Paths to the professoriate: Strategies for enriching the preparation of future faculty. (1st ed.). San Francisco: Jossey-Bass. 